\title{
Perancangan Sistem Informasi Indeks Kematian Pasien Covid-19 Di RSU Proklamasi
}

\author{
Yuliani $^{1}$, Yuda Syahidin ${ }^{2}$, Leni Herfiyanti ${ }^{3}$ \\ Politeknik Piksi Ganesha ${ }^{1,2,3}$ \\ yuliani@piksi.ac.id ${ }^{1}$, yudasy@gmail.com ${ }^{2}$,lenilenzeherfiyanti@gmail.com ${ }^{3}$
}

\begin{abstract}
Abstrak - Rumah sakit merupakan sarana pelayanan kesehatan mulai dari pendaftaran pasien sampai dengan pengelolaan data hasil pelayanan kesehatan yang menghasilkan informasi yang dibutuhkan rumah sakit. Salah satu pengelolaan data yang ada rumah sakit adalah indeks kematian yang diolah di bagian pelaporan rekam medis. Pelaporan kematian menampilkan informasi jumlah kematian dalam suatu kejadian dan menginformasikan jumlah pasien masuk, pasien keluar mati, indeks kematian, dan penyebab kematian.Tujuan dari penelitian ini adalah untuk merancang suatu sistem infromasi yang akurat dengan adanya sistem ini dapat membantu berbagai pihak terutama tenaga kesehatan agar dapat mengakses serta mengetahui penyebab kematian dan wilayah atau daerah terbanyak pada pasien covid-19 pada indeks kematian. Dan berharap hasil ini akan menjadi sebuah solusi untuk rumah sakit itu sendiri untuk meningkatkan SIMRS agar lebih baik. Metode penelitian yang digunakan yaitu kualitatif bersifat deskriptif. Teknik pengumpulan data dengan menggunakan observasi dan studi pustaka. Model perancangan yang digunakan dengan metode air terjun. Hasil dari penelitian menghasilkan sumber sistem informasi indeks kematian pada pasien covid-19.
\end{abstract}

Kata Kunci : Rekam medis. Sistem informasi, Indeks kematian.

Abstract - Hospital is a means of health services ranging from patient registration to the management of data on health care results that produce information needed by hospitals. One of the management of existing data hospitals is the index of deaths processed in the reporting section of medical records. Death reporting displays information on the number of deaths in an event and informs the number of incoming patients, outgoing patients, death index, and cause of death. The purpose of this study is to design an accurate information system with this system can help various parties, especially health workers to be able to access and know the cause of death and the most regions or regions in patients covid-19 in the mortality index. And hope this result will be a solution for the hospital itself to improve the SIMRS for the better. The research method used is qualitatively descriptive. Data collection techniques using observation and library studies. Design model used with waterfall method. The results of the study produced a source of death index information system in covid-19 patients.

Keywords: Medical records. Information system, death index.

\section{PENDAHULUAN}

Rumah sakit merupakan sarana pelayanan kesehatan mulai dari pendaftaran pasien sampan dengan pengelolaan data hasil pelayanan kesehatan yang menghasilkan informasi yang dibutuhkan rumah sakit. Salah satu pengelolaan data yang ada di rumah sakit adalah indeks kematian yang diolah dibagian reporting unit rekam medis. Pelaporan kematian menampilkan informasi jumlah kematian dalam suatu kejadian dan menginformasikan jumlah pasien masuk, pasien keluar mati, indeks kematian, dan sebab kematian.

Pelaporan Kematian mempunyai pengaruh penting di rumah sakit seperti hasil penelitian dari (Marfuatin et al., 2014) menunjukan bahwa data pada kematian dimulai dari pengumpulan berkas data rekam medis di unit rawat inap, sensus harian rawat inap, dan menghasilkan sertifikat kematian. Data kematian yang ada di rumah sakit digunakan untuk pengelolaan indeks kematian, mengelompokan kategori kematian dan mengetahui penyebab kematian.
Pelaporan kematian di gunakan untuk kearsipan data kematian atau sebagai sumber informasi rumah sakit untuk membuat laporan bulanan, triwulan, semester dan tahunan sesuai dengan ketentuan yang ada pada PerMenkes RI NOMOR 1171/MENKES/PER/VI/2011 ada dalam pasal 4 yang bertuliskan yaitu Pelaporan yang bersifat terbarukan setaip saat (update) dan laporan yang bersifat periodik.

Indeks Kematian merupakan indeks tentang penyebab kematian penyakit tertentu dari hasil pelayanan kepada pasien rawat jalan, instalasi gawat darurat atau rawat inap. Disimpan sesuai dengan kategori nama sebab kematian menurut alfabetik (A-Z). Digunakan menelusuri nomor rekam medis dan nama pasien dengan sebab kematian yang sama ,untuk menyusun laporan sebab kematian(Mortalitas) berdasarkan umur, jenis kelamin dan wilayah, mati<48jam, mati>48jam, Dokter yang menangani (Eka et al., 2008).

Virus Severe Acute Respiratory Syndrome (SAR-COV-2) adalah penyakit yang menyerang sistem pernapasan. Penyakit akibat infeksi 
virus ini disebut covid-19. Virus ini menyebabkan gangguan ringan pada sistem respirasi (pernapasan), infeksi pulmo (paru) yang berat, hingga yang menyebakan kematian. Banyak penyakit penyerta yang mempengaruhi kondisi tersebut yang meiliki resiko menyebabkan kematian.

Dengan adanya masalah di atas peneliti tertarik untuk merancang sistem infromasi agar manghasilkan indeks kematian yang berfokus pada pasien covid-19 sehingga sistem inidapat diakses berbagai pihak yang membutuhkan seperti tenaga kesehatan ata pencatatan rumah sakit. Karena sistem informasi tersebut masih milik pemerintah pusat ( untuk laporan data covid) untuk sistem yang dikhusus kan pada indeks kematian pasien covid-19 belum terpenuhi di rumah sakit ini.

Tujuan dari penelitian ini adalah untuk merancang suatu sistem infromasi yang akurat dengan adanya sistem ini dapat membantu berbagai pihak terutama tenaga kesehatan agar dapat mengakses. Serta mengetahui penyebab kematian dan wilayah/daerah terbanyak pada pasien covid-19 pada indeks kematian. Dan berharap hasil ini akan menjadi sebuah solusi untuk rumah sakit itu sendiri untuk meningkatkan SIMRS agar lebih baik.

1. Tinjauan Pustaka

a. Perancangan

Perancangan menurut (O'Brien \& Marakas 2009) menjelaskan Merancang sistem adalah sebuah kegiatan merancang dan menentukan bagaimana mengelola sistem informasi dari hasil analisis sistem sehingga bisa memenuhi keperluan dari user termasuk diantaranya perancangan user interface,data dan aktivitas proses.

\section{b. Sistem}

Sistem adalah orang yang saling bekerja sama dengan ketentuan-ketentuan aturan yang sistematis dan terstruktur untuk membentuk suatu kesatuan yang melaksanakan suatu fungsi untuk mencapai tujuan. Sistem memiliki beberapa karakteristik atau sifat yang terdiri dari komponen sistem, batasan sistem, lingkar luar sistem, penghubung sistem, masukan sistem, keluaran sistem. Adapun pengertian lain yaitu seperangkat elemen-elemen terdiri dari atas manusia, instrumen atau alat dan tata cara serta konsep-konsep yang dirangkum menjadi satu guna tujuan bersama, (Anggraeni \& Rita Irvani 2017)

\section{c. Informasi}

Informasi merupakan suatu data yang dikelola berfungsi dan bermakna bagi penerimanya, serta untuk mengurangi ketidakjelasan dalam proses pengambilan keputusan mengenai suatu keadaan . sistem informasi merupakan suatu konsolidasi teratur dari orang-orang, hardware, software, jaringan komunikasi dan sumber daya data yang mengumpulkan, mengubah, dan menyebarkan informasi dalam sebuah organisasi.

\section{d. Rumah Sakit}

Menurut UU No. 44 Tahun 2009 Tentang Rumah Sakit, Rumah Sakit sebagai salah satu fasilitas pelayanan kesehatan merupakan bagian dari sumber daya kesehatan yang sangat diperlukan untuk mendukung penyelenggaraan upaya kesehatan (Bahriah dkk.2014)

\section{e. Indeks Kematian}

Indeks kematian yaitu indeks tentang sebabsebab kematian penyakit tertentu sebagai hasil pelayanan pasien di instalasi rawat jalan, gawat, atau instalasi rawat inap. Indeks ini tak dapat di hindari antara indeks kematian dengan rawat jalan dan rawat inap. (Wijaya \& Dewi, 2017).

Informasi yang tetap dalam indeks kematian :

- Nama penderita

- Nomor rekam medis

- Jenis kelamin

- Umur

- Kematian : kurang dari sejam post operasi

- Dokter yang merawat

- Hari perawatan

- Wilayah

Manfaat indeks kematian

- Menyusuri nomor rekam medis dan identitas pasien dengan sebab kematian yang sama (untuk audit kematian)

- Menyusun laporan yang menjadi sebab kematian (mortalitas) berdasarkan umur, jenis kelamin, wilayah, Mati< 48 jam dan > 48jam, dokter yang menangani

Kegunaan indeks kematian adalah menilai mutu pelayanan dasar, menambah dan meningkatkan peralatan/tenaga.

\section{METODOLOGI PENELITIAN}

\section{Metode penelitian}

Metode yang digunakan yaitu kualitatif bersifat deskriptif yaitu suatu obyek, fenomena, atau setting sosial yang akan dituangkan dalam tulisan bersifat naratif. Arti dalam penulisannya data dan fakta yang digabungkan berbentuk kata atau gambar dari pada angka.

\section{a. Teknik Pengumpulan data}

a.1 Observasi

Menurut Albi Anggito dan Johan Setiawan (2018) Observasi adalah teknik untuk mengumpulkan data atau informasi dengan melakukan pengamatan terhadap kegiatan secara terstruktur yang sedang berlangsung dalam penelitian ini menggunakan observasi 
partisipasi. Peneliti datang dan ikut dalam melaksanakan kegiatan yang ada di dalam Ruangan rekam medis rumah sakit tersebut.

\section{a.2 Studi Pustaka}

Studi Pustaka adalah teknik akumulasi data dengan melakukan pengkajian terhadap buku, literature, catatan, serta sebagai laporan yang berkaitan dengan masalah yang ingin di pecahkan (Nazir, 1988)

Dalam teknik ini peneliti mengambil referensireferensi seperti jurnal-jurnal dan beberapa buku yang terkait dalam masalah penelitian. Dari proses ini, diharapakan dapat melengkapi informasi-informasi untuk membantu dalam penyelesaian masalah penelitian

\section{Model Perancangan}

Metode Waterfall metode air terjun yang sering disebut waterfall dinamakan siklus hidup klasik ( classic life cycle) nama model ini sebenarnya adalah "Linear Sequential Model, dimana hal ini menguaikan pendekatan yang Tersistematis dan juga tersusun untuk pengembangan perangkat lunak, dimulai dengan spesifikasi kebutuhan pengguna lalu berlanjut melalui tahapan-tahapan perencanaan (planning).

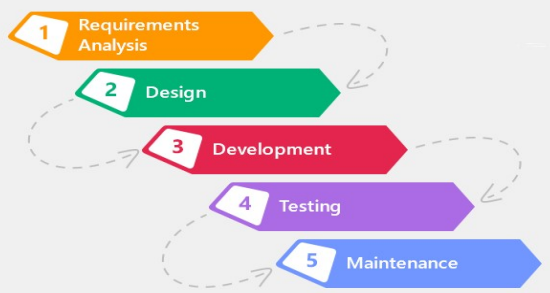

Sumber : Presman (2012)

Gambar 1 Tahapan metode waterfall

\section{HASIL DAN PEMBAHASAN}

\section{Flowmap alur pasien covid}

Dalam proses ini adalah alur pasien datang sampai dengan mendapatkan hasil test. Gambar dapat dilihat yang ada pada Gambar 2 berikut ini.

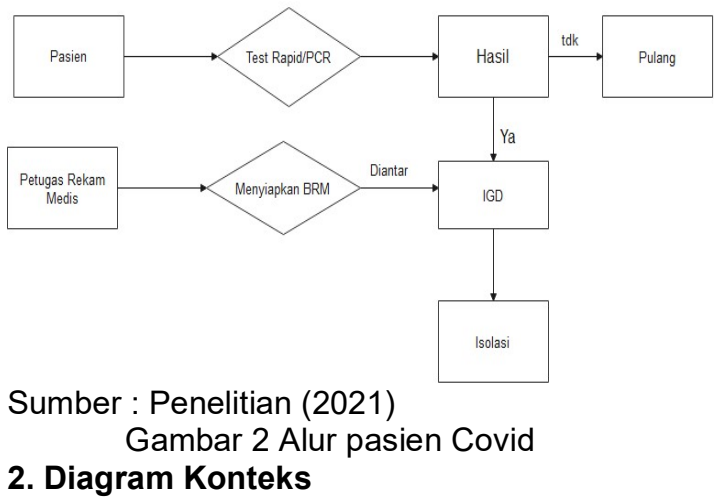

Diagram konteks adalah sebuah diagram sederhana yang menjelaskan koneksi antara entity luar, Input dan Output dari sistem. Diagram konteks dipresentasikan dengan lingkaran tunggal yang menyubstitusi keseluruhan sistem seperti pada Gambar 3

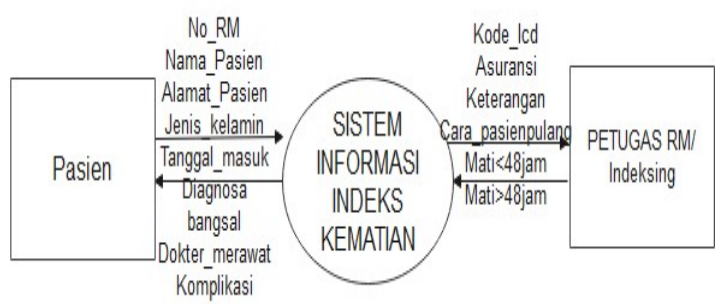

Sumber : Penelitian (2021)

Gambar 3 Diagram Konteks

3. Data Flow Diagram (DFD) LEVEL 0

Pada diagram ini menggambarkan proses hak akses sampai dengan proses pengindeksan kematian itu berjalan.

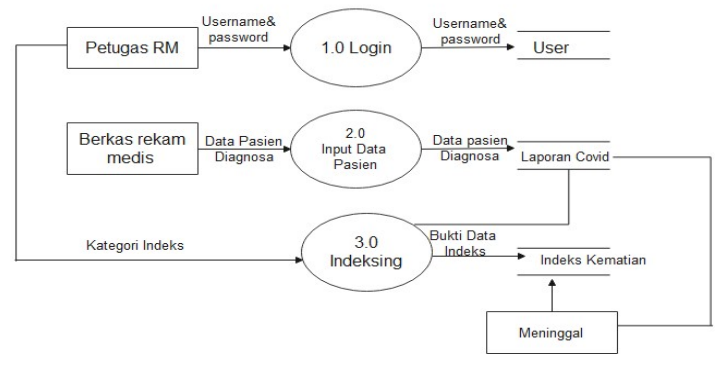

Sumber : Penelitian (2021)

Gambar 4 Data Flow Diagram (DFD) Level 0

4 Entity Relationship Diagram (ERD)

Menurut Brady dan Lonaam(2010), Entity Relationship Diagram (ERD) Merupakan teknik yang digunakan untuk memodelkan kebutuhan data dari suatu organisasi, biasanya oleh sistem analisis dalam tahap analisis persyaratan proyek pengembangan sistem.

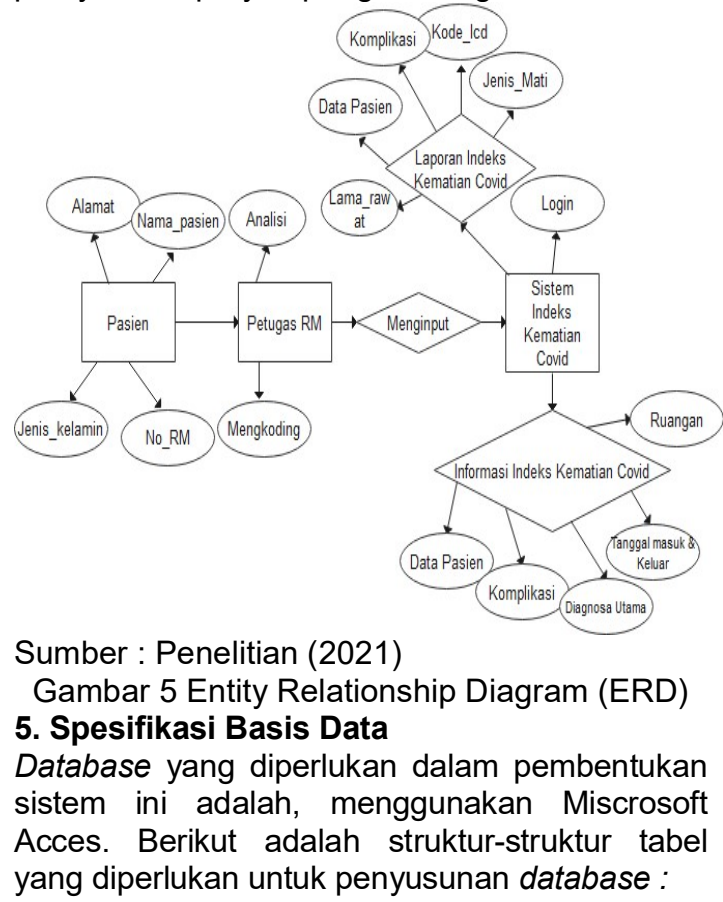


a. Login

Nama tabel

Isi

Primary key

: tb_login

: username,password

: Username

Tabel 1 Spesifikasi Basis Data Login

\begin{tabular}{lll}
\hline Field & Type & Lenght \\
\hline Id_Username & Short Text & 20 \\
Password & Short Text & 10 \\
\hline
\end{tabular}

Sumber : Penelitian (2021)

b. Identitas Pasien

Nama Tabel : tb_identitaspasien

Isi :Datapasien, Hasil pemeriksaan

Primary Key : No_RM

Tabel 2 Spesifikasi basis data Identitas Pasien

\begin{tabular}{llc}
\hline Field & Type & Lenght \\
\hline No_RM & Number & 6 \\
Nama & Short Text & 20 \\
Alamat & Long Text & 40 \\
Jenis_Kelamin & Short Text & 9 \\
Tanggal_Lahir & Short Text & 8 \\
\hline
\end{tabular}

Sumber: Penelitian (2021)

c. Informasi Indeks Kematian

Nama tabel : tb_Informasi

Isi : data pasien

Primary key : No_RM

Tabel 3 Spesifikasi Basis Data Informasi

\begin{tabular}{llc}
\hline Field & Type & Lenght \\
\hline No_RM & Number & 6 \\
Jenis_Kelamin & Short Text & 10 \\
Alamat & Long Text & 40 \\
Umur & Number & 3 \\
Ruangan & Short Text & 10 \\
Tanggal_Masuk & Date/Time & 15 \\
Tanggal_Keluar & Date/Time & 15 \\
Lama_Dirawat & Short Text & 4 \\
Diagnosa_Utama & Short Text & 15 \\
Komplikasi & Short Text & 30 \\
Dokter & Short Text & 30 \\
Jenis_Mati & Short Text & 6 \\
Kode_Icd & Short Text & 20 \\
\hline
\end{tabular}

Sumber : Penelitian (2021)

6. Design Interface

Interface didesain dengan sederhana dan kompleks dengan menampilkan menu home.

a. Form Menu Home

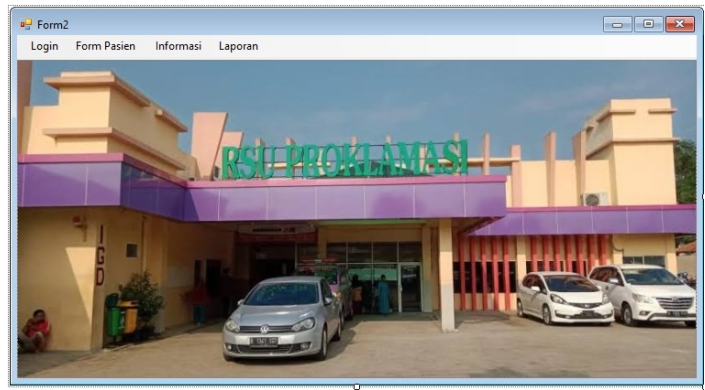

Sumber : Penelitian (2021)

Gambar 6 Menu Home

\section{b. Form Menu Login}

Menu Login didesain dengan sederhana dan kompleks sdengan tampilan username dan password. halaman ini merupakan halaman untuk mendapatkan hak akses untuk mengolah data . desain menu login bisa dilihat pada gambar 10.

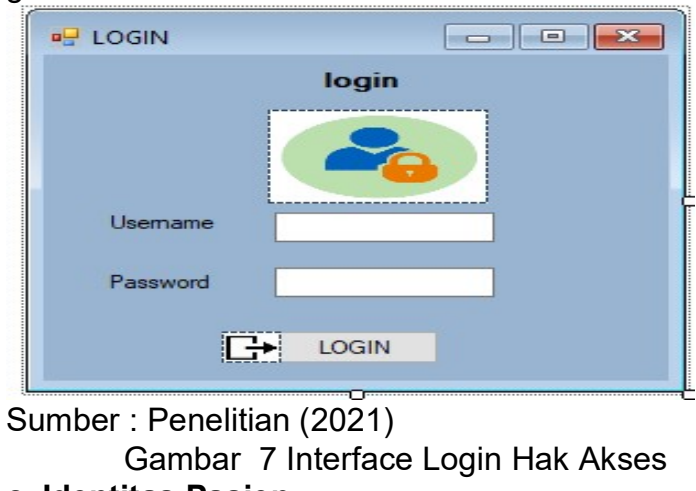

\section{c. Identitas Pasien}

Halaman ini adalah Halaman untuk mengetahui seberapa banyak pasien terkonfirmasi atau tidak ini adalah halaman awal untuk menuju ketahap pengelompokan indeks kematian.

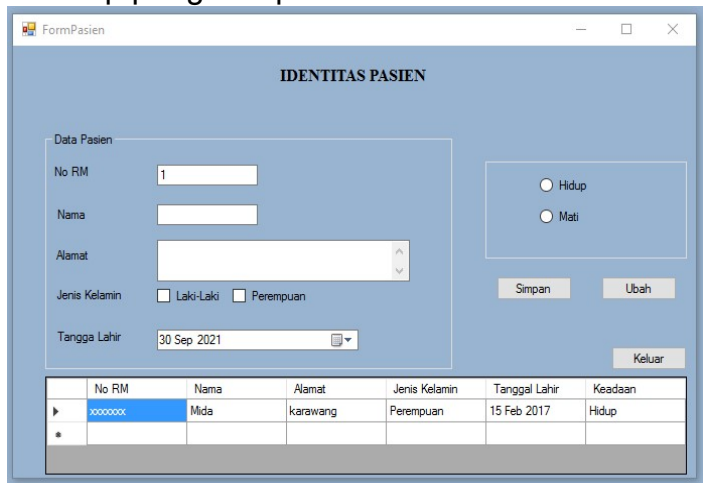

Sumber : Penelitian (2021)

Gambar 8 Halaman Identitas Pasien d.Penginputan Indeks kematian covid

Halaman ini adalah halaman untuk menginput data-data untuk di indeks menjadi sebuah informasi gambar di bawah ini adalah poin-poin data yang harus dimasukan pada indeks kematian covid.

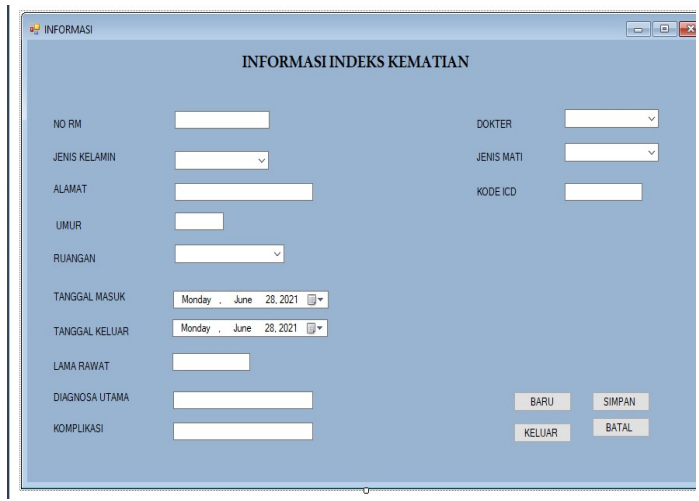

Sumber : Penelitian (2021)

Gambar 9 Halaman input data indeks kematian 


\section{e. Halaman Laporan}

halaman laporan ini adalah guna untuk mengetahui presentanse kematian covid ini , bisa dilihat dalam periode perbulan, tribulan, semester dan satu tahun.

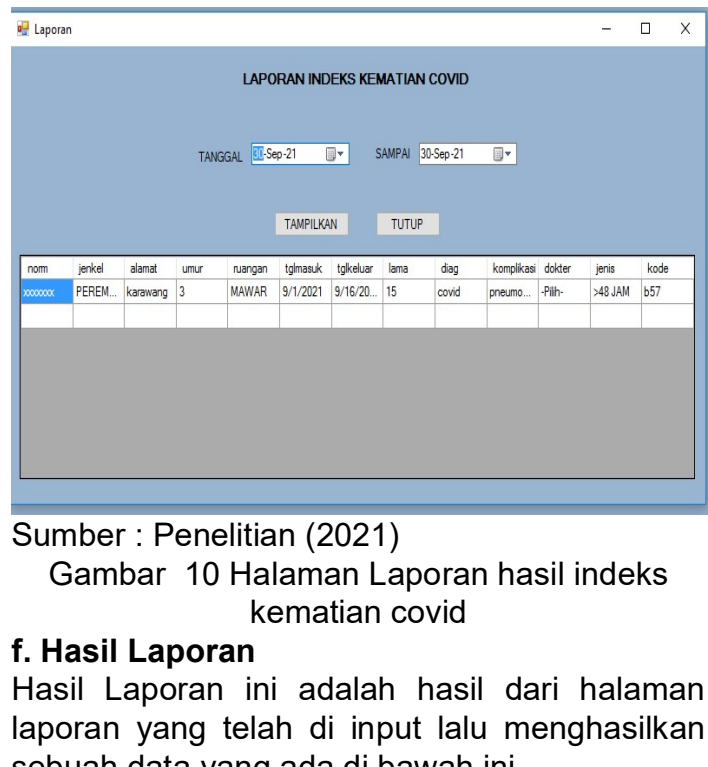
sebuah data yang ada di bawah ini.

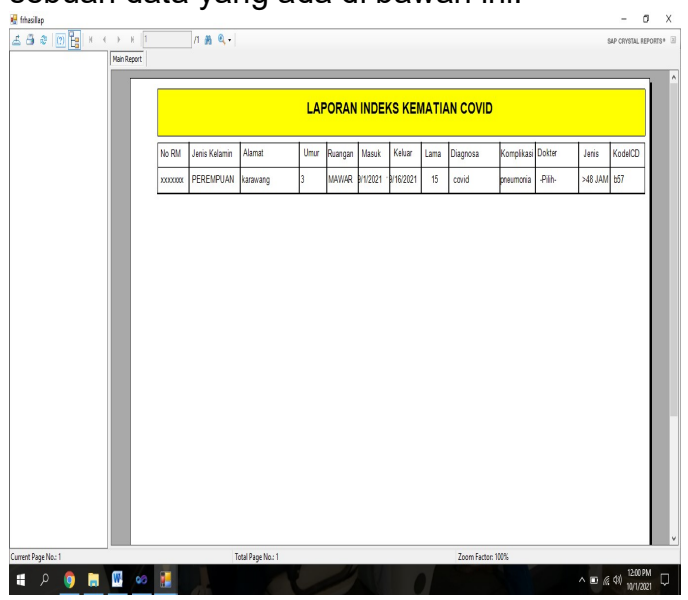

Sumber : Penelitian (2021)

Gambar 11 Hasil Laporan

\section{Pengujian Black Box}

Pengujian Fungsi Form Login untuk mengetahui fungsi dari elemen-elemen form login yang terdapat di halaman sistem . elemen yang diujikan terutama ussername dan password petugas terutama elemen button untuk memproses.

\section{a. Pengujian Black Box Pada Form Login}

Tabel 4 Pengujian Black Box form login

\begin{tabular}{llll}
\hline No & Pengujian & Deskripsi & Pengamatan \\
\hline 1 & Form Login & Petugas & \\
& & Memasukan & \\
& & Username \& & \\
& & Password & \\
& & Jika bener & Berhasil Login \\
& & Jika Salah & Tidak dapat \\
& & Input & masuk \\
\hline
\end{tabular}

\begin{tabular}{rrlr}
\hline 2 & Jengamatan & Sistem akar & Berhasil \\
Button/Login & Memperoses Login \\
& Form
\end{tabular}

Sumber : Penelitian (2021)

b. Pengujian Black Box Pada Form pasien

Gambar 5. Pengujian Black Box form pasien

\begin{tabular}{clll}
\hline No & Pengujian & Deskripsi & Pengamatan \\
\hline 1 & Form & No RM, & Berhasil \\
& Identitas & Nama, & \\
& Pasien & Alamat, & \\
& & Jenis \\
& & Kelamin, & \\
& & Tanggal \\
& & Lahir, Jenis \\
& & Mati (<48 \\
& & jam, $>48$ jam \\
\multicolumn{3}{c}{ Sumber : Penelitian (2021) }
\end{tabular}

Sumber : Penelitian (2021)

\section{KESIMPULAN}

Dari hasil yang didapatkan, dapat diambil kesimpulan sistem infromasi indeks kematian covid ini agar dapat menjadi suatu sumber informasi yang lebih akurat bagi rumah sakit dan mempunyai sistem tersendiri untuk menjadi sumber data yang relevan .

\subsection{Saran}

Perancangan ini yang telah dilakukan , dapat di kembangkan kembali agar dapat terintegrasi dengan SIMRS Dan sistem pusat sehingga sistem ini langsung terserver.

\section{REFERENSI}

Albi Anggito \& Johan Setiawan, S. pd. (2018). Metodelogi Pnelitian Kualitatif (E. D. Lestari (ed.); 2018th ed.). Tim CV Jejak.

Anggraeni, E. Y., \& Rita Irvani. (2017). PENGANTAR SISTEM INFORMASI (E. Risanto (ed.)). CV. ANDI OFFSET.

Bahriah, Sofiyan, A., \& Abdullah, H. F. (2014). Kebijakan Hukum Pidana Dalam Pelayanan Kesehatan. Analisis, 3(1), 12 20.

Eka, S., Sugiarsi, S., SKM, \& Lestari, T. (2008). Manajemen Data Keadaan Morbiditas Rawat Jalan (RL2B) Di Rumah Sakit Umum Daerah Dr.Soediran Mangun Sumarso Wonogiri. Jurnal Kesehatan, 3(2), 44-45.

Marfuatin, A., Lestari, T., \& Mulyono, S. (2014). Tinjauan data kematian di rumah sakit umum daerah $\mathrm{dr}$. soediran mangun sumarso kabupaten Wonogiri tahun 2012. Jurnal Rekam Medis, 2, 22-30.

Nazir, M. (1988). Metode Penelitian.

O'Brien, J. A., \& Marakas, G. M. (2009). Sistem Informasi Manajemen (edisi 9).

Wijaya, L., \& Dewi, D. R. (2017). Manajemen Informasi Kesehatan II: Sistem dan Sub Sistem Pelayanan RMIK (2017th ed., p. 334). 